\title{
Dublin: blind interstatelijk vertrouwen is een fictie
}

\section{Over inwilligingspercentages en overdrachten}

\author{
R. Bruin, S.G. Kok en A. Terlouw*
}

In 1993 stelde toenmalig minister van Justitie Hirsch Ballin dat een asielverzoek door een persoon die elders in een van de landen partij bij de Overeenkomst van Schengen een asielverzoek had ingediend of had kunnen indienen, niet door Nederland in behandeling zou worden genomen, omdat Nederland kon uitgaan van de wijze waarop andere lidstaten asielverzoeken behandelden. Blind vertrouwen had de minister:

\footnotetext{
'Doen wij het anders, (...) dan krijgen wij daar waar een verdeling van verantwoordelijkheid doel is en regel moet zijn, een discussie erover heen over de vraag of je je ongeacht de verantwoordelijkheid van een ander land (...) - nog bezighouden moet met het werk van de partner. Dat doen wij dus niet.'1
}

Maar juist vanaf de jaren negentig kwamen grote verschillen tussen de asielpraktijken in de lidstaten aan het licht. Dat heeft ertoe geleid dat de lidstaten van de Europese Unie (EU) sinds 1999 streven naar harmonisatie van hun asielrecht door middel van bindende regelgeving. Deze regels vormen de bouwstenen van een Gemeenschappelijk Europees Asielsysteem (GEAS). ${ }^{2}$ De aanleiding voor de instelling van het GEAS was het afschaffen van de binnengrenzen in het kader van het vrij verkeer van personen, goederen en diensten. Het doel van het GEAS is het bieden van minimumwaarborgen voor asielzoekers, maar

* Mr. René Bruin is Head of Office UNHCR te Den Haag. Mr. Stefan Kok is docent aan het Instituut voor Immigratierecht van de Universiteit Leiden. Prof. mr. dr. Ashley Terlouw is hoogleraar rechtssociologie aan de Radboud Universiteit Nijmegen.

1 Handelingen // 1992/93, 91-6778.

2 Tijdens de Europese Raad in Tampere 1999 werd de ambitie van een Common European Asylum System geformuleerd. 
misschien meer nog het voorkomen dat de ene lidstaat van de Unie meer bescherming biedt dan de andere door het asielrecht in de Unie te harmoniseren. Een verschil in bescherming zou namelijk enerzijds kunnen leiden tot een onevenredige aantrekkingskracht van de lidstaten met het aantrekkelijkste systeem en anderzijds tot een 'race to the bottom', een poging van elke lidstaat om steeds onder het niveau van bescherming van de buurlanden te blijven. In het kader van het streven naar het GEAS hebben de lidstaten verschillende richtlijnen geformuleerd, onder meer over de definitie van het begrip vluchteling, over de asielprocedure en over de opvang van asielzoekers. Het GEAS begint juridisch vorm te krijgen.

In deze bijdrage zullen we aan de hand van de meest actuele cijfers nagaan of het gelukt is om harmonisatie te bereiken, in het bijzonder met betrekking tot de asielprocedure. We vergelijken daarbij niet de asielprocedures in alle EU-lidstaten. Dat zou een te groot onderzoek vergen. We kijken vooralsnog alleen naar de werking van de Dublinverordening en naar inwilligingscijfers. Wij gaan ervan uit dat deze cijfers in ieder geval een indicatie kunnen geven van het antwoord.

Vervolgens zullen we eerst kort aandacht besteden aan het doel en de inhoud van de Dublinverordening, waarna we bekijken of de praktijk van de overdrachten laat zien dat er vertrouwen tussen de lidstaten bestaat dat de asielprocedures in de lidstaten voldoen aan de minimumnormen zoals te vinden in de EU-Asielprocedurerichtlijn. In deze paragraaf zullen we laten zien dat het Dublin-systeem niet werkt zoals beoogd, onder meer omdat het beginsel van interstatelijk vertrouwen in sommige gevallen niet opgaat.

In de daaropvolgende paragraaf bespreken we de cijfers die ons uit verschillende bronnen bekend zijn over de uitvoering van de Dublinverordening. Daarbij geldt een waarschuwing vooraf. Cijfers geven niet per se een duidelijk beeld van de werkelijkheid. We maken onderscheid tussen (a) cijfers over het aantal overdrachten op grond van de Dublinverordening en (b) cijfers met betrekking tot het aantal asielverzoeken binnen de EU en de inwilligingspercentages. Het doen van harde uitspraken is om verschillende redenen niet eenvoudig. Inwilligingspercentages kunnen personen of verzoeken betreffen (een persoon kan meerdere keren een verzoek indienen), en deze zijn afhankelijk van de herkomst van asielzoekers. Zo zal het inwilligingspercentage in een lidstaat bijvoorbeeld hoger zijn als het een relatief groot aantal verzoeken van asielzoekers uit Syrië behandelt. Tot slot kan 
inwilliging erkenning als vluchteling of subsidiaire bescherming betreffen. In de beginjaren van deze eeuw was er voornamelijk aandacht voor de verschillen in het materiële recht, dat wil zeggen de criteria voor toelating als vluchteling of op andere beschermingsgronden. De aandacht is evenwel verlegd naar de asielprocedures en de opvang, die per lidstaat aanzienlijk verschillen. Het recht op een eerlijke asielprocedure is het meest gedetailleerd uitgewerkt in de herziene Procedurerichtlijn. ${ }^{3}$ Om die reden gaan we tevens in op de Procedurerichtlijn en op de vraag of daarvan een harmoniserend effect kan worden verwacht. De implementatietermijn van de herziene Procedurerichtlijn verloopt op 20 juli 2015. De implementatie in de diverse landen gaat echter moeizaam. ${ }^{4}$ Toch kunnen vanaf 20 juli 2015 - ongeacht of de implementatietermijn is gehaald - asielzoekers zich rechtstreeks op de herziene Procedurerichtlijn beroepen. We eindigen met een korte beschouwing over mogelijke alternatieven.

\section{De Dublinverordening}

Het harmoniseren van het asielrecht krijgt onder meer vorm in de context van afspraken over de verantwoordelijkheidsverdeling van asielzoekers over Europa. De eerste afspraken dateren al van voordat het GEAS tot stand kwam. ${ }^{5}$ Aanvankelijk kwamen deze afspraken tot stand in intergouvernementeel verband tussen de zogenoemde Schengenstaten, later binnen de EU. De Dublinverordening (kortweg Dublin III) regelt welke staat in Europa verantwoordelijk is voor behandeling van een asielverzoek. ${ }^{6}$ Dublin III is op 1 januari 2014 van

3 Richtlijn 2013/32/EU 26 juni 2013 betreffende gemeenschappelijke procedures voor de toekenning en intrekking van de internationale bescherming (herschikking).

4 Uit Kamerstuk 34008, 6, nota naar aanleiding van het verslag, p. 2-3, blijkt dat Portugal de richtlijn heeft ingevoerd, maar dat alle andere EU-lidstaten nog bezig zijn met de omzetting van de richtlijn.

5 De Preambule van de Dublin-conventie van 1990 verwijst hiernaar, PbEG 1997, C 254/1, 19 augustus 1997.

6 Verordening tot vaststelling van de criteria en instrumenten om te bepalen welke lidstaat verantwoordelijk is voor de behandeling van een asielverzoek dat door een onderdaan van een derde land bij een van de lidstaten wordt ingediend, Verordening (EU) 604/2013 van 26 juni 2013. 
kracht geworden en vervangt de oudere Dublin II-verordening, ${ }^{7}$ die weer de Overeenkomst van Dublin van 1990 verving. Het Dublin-systeem gaat uit van vertrouwen tussen de lidstaten dat de asielprocedures in elk van de lidstaten van de Unie eerlijk zijn en dat het niveau van bescherming voldoende is. ${ }^{8}$

Het doel van de afspraken die in Dublin zijn gemaakt, is tweeledig. Het eerste doel is het voorkomen van secundaire migratie ${ }^{9}$ binnen de EU door zeker te stellen dat slechts één lidstaat verantwoordelijk is. Het tweede doel is het voorkomen van het probleem van refugees in orbit (asielzoekers die nergens terechtkunnen) door te garanderen dat een asielzoeker die aan de buitengrenzen of op Europees grondgebied een asielverzoek wil indienen, dit ten minste in één lidstaat van de EU kan doen. ${ }^{10}$

Het Dublin-systeem is geen verdeelsysteem. ${ }^{11}$ Hoewel het Dublin-systeem uitgaat van het beginsel dat inreis via een lidstaat leidt tot verantwoordelijkheid en aannemelijk is dat het merendeel van de asielzoekers via de zuidoostelijke buitengrenzen Europa inreist, leidt de verantwoordelijkheidstoedeling van de beoordeling van asielverzoeken niet tot grote aantallen claims - en overdrachten aan zuidelijke EU-lidstaten. ${ }^{12}$ In de paragraaf 'Cijfers en wat zeggen ze?' zullen we dat op basis van de cijfers onderbouwen. Hier wijzen we er vast op dat,

7 Sinds september 2003 (Dublin II, Verordening (EG) 343/2003) is sprake van een verordening, dat wil zeggen dat de afspraken over de verantwoordelijkheidsverdeling rechtstreekse werking hebben en niet in het Nederlandse recht hoeven te worden geïmplementeerd. Dat neemt niet weg dat Dublin II wel tot enige aanpassing van de Nederlandse wetgeving en beleid heeft geleid.

8 Zie bijv. het argument van het Verenigd Koninkrijk in TI v. UK (ECtHR, nr. 43844/98, 7 maart 2000), dat van lidstaten die zijn aangesloten bij het EVRM verwacht mag worden dat zij de rechten van asielzoekers beschermen.

9 Veelal wordt de term asielshoppen gebruikt. De term asielshoppen is niet nader gedefinieerd en sommige commentatoren wijzen op de verschillende situaties die het kan betreffen. Wij prefereren het gebruik van het meer neutrale begrip 'secundaire migratie' in plaats van asielshoppen. Zie voor het gebruik van de term asielshoppen bijv. Mouzourakis 2014, in de paragraaf 'Cijfers ten aanzien van overdrachten op grond van de Dublinverordening'.

10 Hiervoor geeft Dublin III criteria die zijn gebaseerd op de verantwoordelijkheid van een staat voor binnenkomst, bijv. door visumverlening of vanwege het feit dat de asielzoeker via die lidstaat het Dublin-gebied binnen is gereisd. Het systeem is in overeenstemming met art. 18 van het EU-Handvest van de Grondrechten, waarin het recht op asiel is vastgelegd.

11 Tot op zekere hoogte wordt wel, vanuit het oogpunt van intra-Europese solidariteit, rekening gehouden met lidstaten die een grote druk ondervinden door hoge aantallen asielzoekers, zie considerans Dublin III, punt 21.

12 Uit de cijfers blijkt in ieder geval - voor Nederland - dat ca. 10\% van de asielzoekers (in $\mathrm{NL}$ ) via Schiphol binnenkomt. De overige 90\% doet dat (dus) via de landsgrenzen (auto, boot of trein). 
anders dan de verontwaardiging van de zuidelijke lidstaten doet vermoeden, de meeste asielverzoeken niet in die landen worden ingediend. Al sinds de jaren tachtig van de vorige eeuw wordt gemiddeld genomen de helft van alle asielverzoeken (in Europa) geregistreerd in Duitsland, Frankrijk, Zweden en het Verenigd Koninkrijk. Sinds 2012 is het aandeel van deze vier landen iets toegenomen tot bijna $60 \%$. Die toename komt echter vrijwel volledig voor rekening van Duitsland. In 2007 en 2008 is 16\% respectievelijk 19\% van alle asielverzoeken in Italië en Griekenland ingediend. Het aandeel van Italië en Griekenland is sindsdien afgenomen tot $12 \%$ in 2014 . Ook als alle 'frontstaten' (Italië, Griekenland, Cyprus, Malta en Spanje) bij elkaar worden genomen, wordt in deze zuidgrenslanden gemiddeld zo'n 13\% van alle asielverzoeken geregistreerd. Een soortgelijke berekening voor de oostgrenzen van Europa levert gemiddeld genomen 6\% op. Alleen in 2013 en 2014 is dat percentage fors opgelopen naar ruim $10 \%$ en die toename komt vrijwel volledig voor rekening van Hongarije.

In 2014 kwamen er - volgens de UNHCR - via de zuidgrenzen, via de Middellandse Zee, 218.000 personen de EU binnen (UNHCR 2015b). Het aantal asielverzoeken dat in deze (vijf) zuidgrenslanden wordt ingediend (in 2014), is echter 'maar' 80.000. Dit betekent ofwel dat een belangrijk deel van de asielzoekers die via de zuidgrenzen Europa binnenkomen niet in die landen (maar elders in Europa) een asielverzoek indient, ofwel dat een substantieel deel van deze 218.000 personen in het geheel geen asielverzoek indient.

De motieven om geen asielverzoek in te dienen in een van de zuidgrenslanden kunnen zijn: (1) familie in andere landen, (2) betere opvang verwachten in andere landen, en (3) niet in de gelegenheid worden gesteld door de autoriteiten van de zuidgrenslanden. In 2014 vormden de Syriërs en Eritreeërs volgens UNHCR de grootste groepen die in Italië aankwamen. Toch hebben er in 2014 maar 500 Syriërs en 480 Eritreeërs asiel aangevraagd in Italië. ${ }^{13}$

\section{Interstatelijk vertrouwen}

Vanaf het begin van de uitvoering van het Dublin-systeem rees de vraag of staten er zonder meer op konden vertrouwen dat een asiel- 
zoeker na overdracht behandeld zou worden volgens de normen van het internationaal en Europees asielrecht. Voor een deel kwam deze vraag voort uit verschillende interpretaties van het asielrecht tussen lidstaten en mogelijke beschermingsgaten als gevolg hiervan. ${ }^{14}$ Steeds belangrijker werden daarnaast de zorgen over de toegang tot en de kwaliteit van de asielprocedures en het opvangsysteem in sommige lidstaten aan de buitengrenzen. Waarschijnlijk komt dit ook doordat het Dublin-systeem in eerste instantie was afgesproken tussen een klein aantal 'noordelijke' Schengenstaten, die ervaring hadden met asielprocedures en opvang, en zich geleidelijk andere staten bij het systeem hebben aangesloten. ${ }^{15}$ Daaronder waren ook de niet-EU-lidstaten Zwitserland, Noorwegen en IJsland. Het Dublin-systeem is inmiddels onderdeel van het EU-asielrecht ('Acquis') en ook nieuwe lidstaten moeten dit na toetreding toepassen. Hierdoor zijn sinds 2004 kleine eilandstaten als Malta en Cyprus, en andere lidstaten aan de zuidelijke en oostelijke grenzen, volwaardig onderdeel van het Dublinsysteem en het Gemeenschappelijk Asielstelsel. 'Oudere’ lidstaten die voorheen als doorreislanden fungeerden, zoals Griekenland, Italië en Spanje, moesten hun asielprocedure vanaf 2004 aanpassen aan EUasielnormen en werden gemaand mee te werken aan het Eurodacregistratiesysteem ${ }^{16}$ en de grensbewaking. Hierbij worden zij bijgestaan en gevolgd door Frontex ${ }^{17}$ en door het European Asylum Support Office (EASO) ${ }^{18}$ met de zogenoemde asylum support teams.

De zorgen over het niveau van de asielprocedures en opvang bestonden al geruime tijd voordat het Europees Hof voor de Rechten van de Mens (EHRM) in 2011 de baanbrekende uitspraak in de zaak MSS v. België en Griekenland deed, waarin het oordeelde dat er ten aanzien van Griekenland geen plaats was voor interstatelijk vertrouwen. Ook uit de beantwoording van de prejudiciële vragen in de zaken NS en ME door het Hof van Justitie van de EU ${ }^{19}$ blijkt dat van blind interstatelijk

14 EHRM 7 maart 2000, appl. nr. 43844/98 (TI v. VK).

15 In 1990 werd de voorloper van de Dublin-conventie, de Schengenuitvoeringsovereenkomst, getekend door de Benelux-landen en Frankrijk en Duitsland.

16 In het Eurodac-systeem worden vingerafdrukken van asielzoekers opgenomen.

17 EU-lidstaten zijn in eerste instantie zelf verantwoordelijk voor de bewaking van de buitengrenzen. De EU wil tot een gemeenschappelijke bewaking van de buitengrenzen van de EU komen. Frontex heeft een coördinerende rol.

18 Het bureau werd in 2010 opgericht. EASO ondersteunt de EU-lidstaten door het doen van onderzoek en het organiseren van opleidingen en bijeenkomsten voor ambtenaren en beleidsmakers van de lidstaten.

19 HvJ EU 21 december 2011, C-411/10 (NS v. SSHD); HvJ EU 21 december 2011, C-493/10 (NS) en C-411/10 (ME e.a.). 
vertrouwen geen sprake mag zijn. Er is altijd een onderzoeksplicht en die is groter naarmate er meer aanwijzingen zijn dat het asielsysteem en/of de opvang in een lidstaat niet in orde zijn.

Er is in Nederland inmiddels veel jurisprudentie over Dublin III.

Vooral met betrekking tot Italië. Over Griekenland bestaat na de uitspraken van Europese rechters geen twijfel dat het kwalitatief onvoldoende procedures heeft, maar ook over Italië ${ }^{20}$ en over de asielprocedures in Hongarije, ${ }^{21}$ Bulgarije en Roemenië ${ }^{22}$ bestaan zorgen. Een van de problemen is dat asielzoekers na overdracht in die landen langdurig worden gedetineerd. Dat kan overdracht in de weg staan. Afhankelijkheid van een familielid dat verblijft in de verzoekende staat vormt eveneens een beletsel, zie bijvoorbeeld de uitspraak met betrekking tot Polen ${ }^{23}$ en met betrekking tot Italië. ${ }^{24}$

Tot nu toe is uitsluitend het terugsturen naar Griekenland in zijn algemeenheid verboden, maar in de zaak Tarakhel van 2014 heeft het EHRM geoordeeld dat het terugsturen door Zwitserland van een groot Afghaans gezin naar Italië in strijd is met artikel 3 van het Europees Verdrag tot bescherming van de rechten van de mens en de fundamentele vrijheden (EVRM), omdat het de kans dat het gezin dakloos zou worden en de gezinsleden zouden worden gescheiden te groot achtte. In deze uitspraak verwijst het EHRM uitvoerig naar de MSSuitspraak en legt het uit dat de situatie in Italië niet vergelijkbaar is met die in Griekenland. Niettemin oordeelt het dat uitzetting niet mag mede omdat het om kinderen gaat en kinderen speciale bescherming behoeven, waarbij het niet ter zake doet dat zij vergezeld zijn door hun

20 Op 8 januari 2015 maakte het EHRM bekend dat twee zaken, Dublin III betreffend, naar Nederland zijn gecommuniceerd: K.O.J. v. Nederland (appl. nr. 7149/12) en S.M.H. v. Nederland (appl. nr. 5868/13).

21 Zie recentelijk Rb. Den Bosch (VK) 20 maart 2015, AWB 15/2753, en eerder EHRM 6 juni 2013, appl. nr. 2283/12 (Mohammed v. Oostenrijk) en EHRM 3 juli 2014, appl. nr. 71932/12 (Mohammadi v. Oostenrijk). Zie ook 'Hongarije pest asielzoekers weg', Trouw 20 maart 2015. In de eerste twee maanden van 2015 werden 28.535 asielaanvragen ingediend. Er wordt gerept over detentie van asielzoekers en het afwerken van asielaanvragen in luttele dagen, zonder mogelijkheid van beroep.

22 Rb. Den Haag (VK Rotterdam) 29 december 2014, AWB 14/27398, vovo toegewezen. Op 31 maart 2015 berichtte ATS - Agence Télégraphique Suisse over het feit dat UNHCR zich in scherpe bewoordingen had uitgelaten over de dood van twee Yezidi's als gevolg van mishandeling door Bulgaarse grenswachten. Zie ook www.unhcr.org/551abb606.html. $23 \mathrm{Rb}$. Den Haag (VK Amsterdam) 20 februari 2015, AWB 14/27776, vovo toegewezen.

24 Rb. Den Haag (VK Haarlem) 4 maart 2015, AWB 14/16657, beroep gegrond. 
ouders. De opvangfaciliteiten moeten in overeenstemming zijn met hun leeftijd. ${ }^{25}$

De uitspraken MSS en NA/ME zijn inmiddels verwerkt in artikel 3 lid 2 Dublin III (Costello 2012; Moreno-Lax 2012; Brouwer 2013). Als ernstig moet worden gevreesd dat de asielprocedure en de opvangvoorzieningen voor verzoekers in die lidstaat systeemfouten bevatten die resulteren in onmenselijke of vernederende behandelingen in de zin van artikel 4 van het EU-Handvest van de Grondrechten (dat is gebaseerd op art. 3 EVRM), moet overdracht achterwege blijven. De Tarakhel-uitspraak maakte duidelijk dat overdracht aan Italië een schending van artikel 3 EVRM zou kunnen opleveren, ook al is niet bewezen dat er sprake is van systematische tekortkomingen in de Italiaanse asielprocedure dan wel met betrekking tot de opvang.

Opmerkelijk is dat een eerstelijns Duitse rechter zelfs reden zag om geen interstatelijk vertrouwen in Nederland meer te hebben. ${ }^{26}$ Overdracht naar Nederland werd opgeschort omdat opvangvoorzieningen voor uitgeprocedeerde asielzoekers niet voorhanden zijn.

Wij concluderen dat in de waarborgen tegen een afwijzing op grond van verantwoordelijkheid van een andere lidstaat van de EU in het kader van de Dublinverordening een grote verandering is opgetreden. Daar waar in de beginjaren van het bestaan van overeenkomsten met betrekking tot exclusieve verantwoordelijkheidstoedeling van overheidswege werd gesteld dat een asielverzoek van een persoon die in een ander EU-land was geweest imperatief diende te worden afgewezen, ${ }^{27}$ is, mede onder invloed van de rechtspraak van het EHRM, Dublin III in de loop der jaren zodanig gewijzigd dat er expliciet in de tekst van de verordening is opgenomen dat er een rechtsmiddel moet zijn tegen een afwijzing op grond van Dublin III. Artikel 27 van Dublin III luidt als volgt:

25 EHRM (Raad van Europa: Europees Hof voor de Mensenrechten) 4 november 2014, appl. nr. 29217/12, JV 2014/384 m.nt. Battjes (Tarakhel v. Zwitserland), te raadplegen op: www.refworld.org/docid/5458abfd4.html.

26 Verwaltungsgericht Darmstadt 8 mei 2014, JV 2014/188.

27 Art. 30 lid 1 onder a VW 2000 ademt die stelligheid nog steeds uit: “Een aanvraag tot het verlenen van een verblijfsvergunning voor bepaalde tijd als bedoeld in artikel 28 wordt afgewezen indien: a. een ander land, partij bij het Vluchtelingenverdrag ingevolge een verdrag of een dit land en Nederland bindend besluit van een volkenrechtelijke organisatie verantwoordelijk is voor de behandeling van de aanvraag.' 
'De verzoeker of een andere persoon als bedoeld in artikel 18, lid 1, onder c) of d), heeft het recht tegen het overdrachtsbesluit bij een rechterlijke instantie een daadwerkelijk rechtsmiddel in te stellen, in de vorm van een beroep of een bezwaar ten aanzien van de feiten en het recht.'

De Rechtbank Den Bosch heeft in verband hiermee op 2 februari 2015 drie prejudiciële vragen gesteld. ${ }^{28}$ De rechtbank wil weten of onder Dublin III een fundamentele hervorming heeft plaatsgevonden van het recht op een effectief rechtsmiddel. Hoe ver strekt de reikwijdte van artikel 27 van Dublin III? Is er voor een asielzoeker altijd een mogelijkheid de overdracht aan te vechten, ook al heeft de aangezochte staat ingestemd met de overdracht? Zijn er naast een situatie van systeemgerelateerde tekortkomingen en de in de Verordening genoemde belangen van met name gezinnen, nog andere bijzondere omstandigheden die zich kunnen verzetten tegen een overdracht?

\section{Cijfers en wat zeggen ze?}

Cijfers over de uitvoering van Dublin III moeten aan de Europese Commissie en het Europees Parlement worden verstrekt op grond van Verordening (EG) 862/2007 van het Europees Parlement en de Raad van 11 juli 2007 betreffende communautaire statistieken over migratie en internationale bescherming. ${ }^{29}$

Artikel 47 van Dublin III expliciteert dat overeenkomstig artikel 4 lid 4 van die verordening de lidstaten aan de Commissie (Eurostat) statistieken verstrekken over de toepassing van de onderhavige verordening en van Verordening (EG) 1560/2003. Zowel Eurostat als het EASO verstrekt cijfers. In de inleiding wezen we er al op dat de beschikbare cijfers niet altijd een duidelijk beeld van de werkelijkheid geven. Dat geldt ook voor de cijfers omtrent de uitvoering van Dublin III. Bij de interpretatie van de cijfers met betrekking tot het Dublin-systeem moet daarom voorzichtigheid worden betracht. ${ }^{30}$

Mouzourakis merkt weliswaar op dat door hechte samenwerking tussen Eurostat en EASO er sprake is van een significante verbetering in 
de harmonisatie van cijfermateriaal (Mouzourakis 2014, par. 4), maar hij verwijst ook naar een rapport van de European Council on Refugees and Exiles (ECRE), waarin staat dat veel landen geen gedetailleerde gegevens hebben verstrekt, met name niet over Dublin-claims en overdrachten (Mouzourakis 2014, par. 2). In dit rapport, getiteld Lives on hold, stelt ECRE ook dat er methodologische problemen zijn bij de statistieken (ECRE 2013, p. 21, 23). In het onderstaande geven we daarom met enig voorbehoud de beschikbare cijfers, waarbij we onderscheid maken tussen cijfers ten aanzien van overdrachten op grond van Dublin III en cijfers met betrekking tot inwilligingspercentages.

\section{Cijfers ten aanzien van overdrachten op grond van Dublin III}

Toen het Dublin-systeem in 2007 werd geëvalueerd door de Europese Commissie was eigenlijk de conclusie dat het systeem wel werkte om asylum shopping te constateren, ${ }^{31}$ maar dat het systeem slechts in beperkte mate leidde tot overdrachten van nieuwe asielzoekers tussen landen aan de binnengrenzen naar landen aan de buitengrenzen. ${ }^{32}$ ECRE merkte op dat het aantal overdrachten laag is in verhouding tot het aantal asielaanvragen en laag is gezien het aantal aanvaarde overdrachten. In de periode 2003-2005 werden bijna 600.000 asielverzoeken ingediend (in EU-lidstaten; als de overige landen van Europa ook worden meegenomen, gaat het om een totaal van 850.000). In 40.000 gevallen leidde dit tot een aanvaarding van de claim en zou overdracht kunnen plaatshebben. Uiteindelijk werden 16.000 personen daadwerkelijk overgedragen. Het systeem werd door ECRE om die reden niet effectief genoemd (ECRE 2013, p. 21). Wat daarvan zij, in ieder geval moet worden geconstateerd dat veel onderzoek en veel contact over en weer niet leidden tot een overdracht. Het Dublin-systeem heeft niet geleid tot het gehoopte tegengaan van secundaire migratie.

Het is de vraag of in de hierboven weergegeven trends verandering is gekomen door een betere coördinatie en registratie van asielzoekers,

31 Zo werd in 2005 in 16\% van 187.000 gevallen geconstateerd dat een asielzoeker reeds in een andere lidstaat asiel had aangevraagd. Evaluatie van Dublin III in 2007 (COM(2007)299 def. van 6 juni 1997, p. 5).

32 In de onderzoeksperiode 2005 werden 3.055 asielzoekers naar lidstaten aan de buitengrenzen overgedragen en 5.161 naar landen aan de binnengrenzen: Evaluatie van Dublin III in 2007 (COM(2007)299 def. van 6 juni 1997, p. 12). ECRE betwistte deze conclusie en stelde dat landen aan de buitengrenzen meer overdrachten krijgen (ECRE 2008, p. 13). 
met name in het Eurodac-systeem. Uit de cijfers van Eurostat in $2014^{33}$ over de periodes tussen 2008 en 2012 blijkt dat er in verhouding tot de instroom procentueel meer verzoeken om overdracht werden gedaan dan in 2005. Het ging in 2008 en 2009 om tussen de 40.000 en 50.000 verzoeken op een instroom van 226.000 asielzoekers in 2008, respectievelijk 266.000 in 2009. In de periode tussen 2008 en 2012 werden er - net als in de periode rond 2005 - meer verzoeken om terugname (vanwege het reeds hebben ingediend van een asielverzoek in een andere staat) ingediend dan verzoeken om overname (van asielzoekers die nog een aanvraag moeten indienen). Uiteindelijk leidden verzoeken om overdracht in $30 \%$ van de gevallen tot daadwerkelijke overdracht. De landen die in 2012 in totaal de meeste asielzoekers overgedragen hebben, waren:

- Zwitserland (4.600), meest aan Italië, Spanje en Frankrijk;

- Duitsland (3.000), meest aan Italië, Polen en België;

- Zweden (1.700), meest aan Italië, Duitsland en Noorwegen.

Italië kreeg verreweg de meeste verzoeken om overname in 2012. Hierbij zij aangetekend dat overdrachten aan Griekenland in 2012 niet konden plaatsvinden vanwege de uitspraak MSS v. België en Griekenland van het EHRM in 2011, zoals hierboven opgemerkt. ${ }^{34}$ Concluderend kunnen we vaststellen dat de cijfers niet duiden op een soepele toepassing van Dublin III. Er wordt veel tijd gestoken in het onderzoek van de mogelijkheid een claim te leggen en het daadwerkelijk leggen van een claim, terwijl het aantal gerealiseerde overdrachten ver achterblijft bij de gelegde claims. Dit roept twijfels op bij het nut van het Dublin-systeem. Bovendien bleek uit de evaluatie van Dublin I dat het aantal claims tussen westelijke staten vrijwel neutraal was en dat er nauwelijks claims op de zuidelijke staten werden gelegd. Onder Dublin II lijkt hierin weinig verandering te zijn gekomen (ECRE 2013, p. 21, 23).

\section{Cijfers met betrekking tot inwilligingspercentages}

We waarschuwen opnieuw: cijfers zijn niet alleen niet altijd duidelijk, ze zijn ook niet per se met elkaar te vergelijken. Zo werden in Neder-

33 Zie http://ec.europa.eu/eurostat/statistics-explained/index.php/Dublin_statistics_on_ countries_responsible_for_asylum_application\#Further_Eurostat_information.

34 EHRM 21 januari 2011, appl. nr. 30696/09, A\&MR 2011, afl. 1, p. 32-33 m.nt. Spijkerboer, A\&MR 2011, afl. 2, p. 66-74 m.nt. Battjes (M.S.S. v. België en Griekenland). 
land nareizigers - personen die in het kader van gezinshereniging met vluchtelingen naar Nederland komen - tot 28 maart 2014 meegeteld bij het aantal eerste asielaanvragen. ${ }^{35}$ Daarnaast dient onderscheid te worden gemaakt tussen alle verzoeken die in het kader van asiel worden verwerkt (een indicatie van de werklast van de IND) en het aantal eerste asielverzoeken dat in een bepaalde periode wordt ingediend (een indicatie van het aandeel van de totale instroom). Het al dan niet meetellen van nareizende familieleden in de asielstatistieken is dan verwarrend omdat het verzoek van deze nareizende familieleden weliswaar per definitie wordt ingewilligd, maar zij krijgen - in Nederland althans - een reguliere vergunning. Het is onduidelijk in hoeverre de overige landen in Europa op een dergelijke wijze omgaan met het registreren van nareizende familieleden.

Uit de cijfers over 2013 kwam naar voren dat 3.078 Somaliërs in Nederland een asielverzoek hebben ingediend. Later bleek dat het ongeveer $80 \%$ nareiszaken, dus gezinshereniging, betrof. Het afzonderlijk registreren van nareizigers is beslist inzichtelijker, maar de vergelijkbaarheid met voorgaande jaren wordt erdoor vertroebeld. Het 'weglaten' van nareiscijfers heeft invloed op het inwilligingspercentage. De staatssecretaris merkte augustus 2014 op dat Nederland, nu het (zoals ook Frankrijk doet) de nareisinwilligingen onderbrengt bij reguliere verzoeken - niet asielverzoeken -, onder het Europees gemiddelde zit wat betreft het inwilligingspercentage met betrekking tot asielverzoeken. ${ }^{36}$ Dat is echter niet het gehele verhaal. De Nederlandse asielcijfers hebben gedurende lange tijd niet zozeer de instroom van nieuwe asielzaken weergegeven, als wel de totale werklast van de IND. Dat resulteerde in structureel te hoge cijfers: te hoog als het ging om het aandeel (in Europese context) en nu dus ook als het gaat om het inwilligingspercentage. Daarnaast moet rekening worden gehouden met de overweging dat de cijfers over de Nederlandse procedure alleen vergelijkbaar zijn met procedures in andere landen waarbij de bezwaarprocedure expliciet wordt meegenomen. In Nederland zit die immers 'verstopt' in de voornemenprocedure.

Een andere verwarring betreft de afwijzingspercentages. Wordt een afwijzing op grond van het feit dat een ander land verantwoordelijk is voor de behandeling van het asielverzoek meegeteld bij de berekening 
van het inwilligingspercentage? Kennelijk bestaat hierover onduidelijkheid (Mouzourakis 2014, par. 2.2). In Nederland wordt een negatieve beschikking op grond van Dublin III als een afdoening en niet als een afwijzing genoteerd. Deze wordt dus niet meegewogen bij de berekening van het inwilligingspercentage, aldus de IND.

\section{Inhoudelijke harmonisatie?}

Wat kan naar aanleiding van de cijfers worden gezegd over inhoudelijke harmonisatie? Algemene inwilligingspercentages zijn weinigzeggend. De compositie van de asielpopulatie bepaalt het algemene inwilligingspercentage. Een land als Italië, waar vooral Malinezen, Nigerianen en Pakistanen asielverzoeken indienden, is niet vergelijkbaar met Nederland, waar vooral Syriërs en Eritreeërs binnenkwamen (UNHCR 2015a, p. 11). Het is inzichtelijker om naar de inwilligingspercentages met betrekking tot asielzoekers uit bepaalde herkomstlanden te kijken. In Nederland is het grootste aantal aanvragen het afgelopen jaar afkomstig van Syriërs. Dat is niet in alle landen van de EU het geval. Het EASO-rapport over 2012 liet zien dat er grote verschillen bestonden met betrekking tot de beoordeling van Syrische asielzoekers. Waar in veel landen een zeer hoog inwilligingspercentage te zien was, in Duitsland bijvoorbeeld 89\%, presteerden Cyprus en Ierland het om een inwilligingspercentage van $0 \%$ te genereren (EASO 2013, p. 28). Ten aanzien van Nederland bevat het EASO-rapport geen data. Ook als het gaat om Afghaanse asielzoekers komen grote verschillen aan het licht: in 2013 is het inwilligingspercentage voor deze groep in Zweden 23\%, in Denemarken 34\%, in Nederland 56\% en in Finland $86 \%$ (EASO 2014, p. 26).

\section{De herziene Procedurerichtlijn}

Voor interstatelijk vertrouwen is vertrouwen in elkaars procedures nodig, dat wil zeggen dat die procedures in elk geval niet onder een bepaald minimumniveau mogen zijn. Dat geldt zowel voor de aanvraagprocedures als voor de procedure bij de rechter. Om dit te realiseren is Procedurerichtlijn 2005/83 ${ }^{37}$ tot stand gebracht. Een eerste 
poging tot harmonisatie. De richtlijn stelde minimumeisen aan de asielprocedure. Het kostte behoorlijk veel moeite om de lidstaten van de EU het eens te laten worden over de Procedurerichtlijn. Dat heeft verschillende redenen (Boeles e.a. 2014, p. 246-250).

In de eerste plaats verschilde het administratieve kader voor het behandelen van asielverzoeken tussen de lidstaten aanmerkelijk, en dat is nog steeds het geval. In beginsel is er sprake van nationale procedurele autonomie. ${ }^{38}$ De wijze waarop het EU-recht ten uitvoer wordt gelegd, is, bij een gebrek aan een Unierechtelijke regeling dienaangaande, een zaak van de rechtsorde van de lidstaten. Bovendien vallen in de meeste lidstaten asielprocedures onder het bestuursrecht en op het niveau van het algemene bestuursrecht is nauwelijks sprake van harmonisatie. Tot slot was er anders dan bijvoorbeeld met betrekking tot het materiële asielrecht, ${ }^{39}$ geen duidelijk internationaalrechtelijk kader met betrekking tot procedurele regels voor asielprocedures. Het VN Vluchtelingenverdrag bevat nauwelijks procedurele bepalingen en artikel 6 EVRM is nooit van toepassing geacht in asielprocedures, omdat die bepaling is beperkt tot burgerlijke en strafrechtelijke procedures. ${ }^{40}$

\section{Algehele harmonisatie}

Inmiddels is de oude Procedurerichtlijn herzien. ${ }^{41}$ De implementatietermijn van de herziene Procedurerichtlijn (Pri) verloopt op 20 juli 2015. Dat wil zeggen dat asielzoekers zich vanaf dat moment - ongeacht of de implementatietermijn is gehaald - rechtstreeks op de herziene Procedurerichtlijn kunnen beroepen. De belangrijkste verandering is dat de richtlijn geen minimumnormen meer biedt, maar beoogt een algehele harmonisatie tot stand te brengen. ${ }^{42}$

De voornaamste procedurele rechten in asielzaken zijn als volgt samen te vatten:

38 HvJ EU 7 januari 2004, C-201/02 en HvJ EU 4 juli 2006, C-212/04.

$39 \mathrm{Er}$ bestaat sinds 1979 een UNHCR Handbook on procedures and criteria for determining refugee status, dat met name materieelrechtelijke uitleg geeft aan bepalingen uit het VN Vluchtelingenverdrag.

40 EHRM 5 oktober 2000, appl. nr. 39652/98 (Maaouia v. Frankrijk).

41 Richtlijn 2013/32/EU van 26 juni 2013 betreffende gemeenschappelijke procedures voor de toekenning en intrekking van de internationale bescherming (herschikking).

42 Nederland heeft in het wetsvoorstel tot implementatie van de Procedurerichtlijn veel duidelijker dan voorheen aansluiting gezocht bij de bepalingen in de Asielprocedurerichtlijn. 
- het recht om een asielverzoek te doen (preambule 13 en art. 6 Pri). Elk verzoek om bescherming wordt aangemerkt als asielverzoek, tenzij betrokkene expliciet om een andere vorm van bescherming verzoekt (art. 2b Pri);

- het recht op een eerlijke behandeling van het asielverzoek, dat wil onder meer zeggen het recht op een persoonlijk interview (art. 14-17 Pri), rechtsbijstand (art. 19-23 Pri), UNHCR (art. 12.1c en 29 Pri), een tolk (art. 12.1b Pri), een deugdelijk onderzoek (art. 10.3 Pri) en een gemotiveerde schriftelijke beslissing (art. 9 Pri) binnen een redelijke termijn (art. 12.1f en 31 Pri) door een competente autoriteit (art. 4.3 Pri);

- het recht om gedurende de behandeling in de lidstaat te blijven (tenzij een andere lidstaat verantwoordelijk is of sprake is van een vervolgaanvraag) (art. 9 en 40-41 Pri);

- het recht op een effectief rechtsmiddel voor een rechterlijke instantie (art. 46 Pri en zie ook art. 13 EVRM en art. 47 Handvest).

Voor het interstatelijk vertrouwen is uiteraard de vraag cruciaal of de herziene Procedurerichtlijn tot eenvormige, eerlijke procedures - en daarmee voor vergelijkbare inwilligingspercentages voor asielzoekers uit dezelfde landen van herkomst c.q. met vergelijkbare vluchtverhalen in de EU - zal leiden. Wij achten dat onwaarschijnlijk. Law in books is nog geen law in action. De huidige zorgen over bijvoorbeeld de asielprocedure in Griekenland ${ }^{43}$ zullen met de nieuwe Procedurerichtlijn niet als sneeuw voor de zon verdwijnen.

Ook het EU-Handvest van de Grondrechten, dat in artikel 47 het recht op een eerlijke procedure voor de rechter geeft (en in art. 41 een recht op eerlijke bestuurlijke procedures), zal niet zonder meer tot procedurele harmonisatie leiden. Wel geven het Handvest, de nieuwe Procedurerichtlijn en Dublin III een stevige juridische basis voor claims tegen overdracht aan landen die hun asielprocedure niet op orde hebben.

Materiële verschillen blijven natuurlijk ook een rol spelen. Recent is nog gebleken dat het uitbrengen van een gezamenlijk ambtsbericht inzake Libië ${ }^{44}$ er niet toe leidde dat de vier landen die het bericht uitbrachten - België, Nederland, Noorwegen en Zweden - tot eenzelfde

43 UNHCR observations on the current asylum system in Greece, zie www.refworld.org/docid/ 54cb3af34.html.

44 Libya: Security situation, rapport van 19 december 2014, te raadplegen op: www.refworld. org/docid/54afd82d4.html. 
inschatting kwamen. Het betrof de toepasselijkheid van artikel 15c van de Definitierichtlijn (Defri) over het verlenen van subsidiaire bescherming aan burgers die door willekeurig geweld in een situatie van gewapend conflict grote risico's lopen. In een brief van 16 januari 2015 beoordeelde voormalig staatssecretaris Teeven de situatie in Libië niet als een situatie vallend onder artikel 15c Defri. ${ }^{45}$ België (medeauteur van het ambtsbericht van 19 december) voert volgens de hiergenoemde brief van 16 januari wel een 15c-beleid. Zweden voert ook een 15c-beleid en Noorwegen heeft een vertrekmoratorium ingesteld. ${ }^{46}$

\section{Alternatieven}

Hoewel het voorkomen van secundaire migratie een duidelijk doel is van het Dublin-systeem, is het Dublin-systeem geen verdeelsysteem. De roep om een verdeelsleutel wordt steeds groter. ${ }^{47}$ In Nederland heeft de Adviescommissie voor Vreemdelingenzaken (ACVZ) de opdracht gekregen te komen met een voorstel. ${ }^{48}$ De verschillen in asielcijfers zijn groot, waarbij Midden-Europese en Noord-Europese staten nog steeds de meeste asielzoekers ontvangen. Of dit betekent dat deze lidstaten een onevenredig aantal asielzoekers ontvangen, is een tweede. Er is geopperd om een EU-systeem op te zetten waarbij lidstaten naar draagkracht asielzoekers of vluchtelingen ontvangen. Nationaal zijn er wel verdeelsystemen, zoals dat van Duitsland, dat een 'Königsteiner Schlüssel' hanteert waarbij deelstaten op basis van de factoren bevolking (een derde) en belastingopbrengsten (twee derde) een quotum asielzoekers krijgt toegewezen. ${ }^{49}$ Oostenrijk stelt in een plan 'Save lives' een aantal mogelijke verdeelsystemen voor, gebaseerd op demografische en economische factoren. ${ }^{50}$ Het plan geeft per model aan welke staten eventueel meer of minder asielzoekers zouden

45 Brief van de staatssecretaris van Veiligheid en Justitie d.d. 16 januari 2015, Kamerstukken // 2014/15, 19637, 1942.

46 Bron: UNHCR Zweden.

47 Motion for a resolution, 27 april 2015, zie www.europarl.europa.eu/sides/getDoc.do?type= MOTION\&reference $=$ B8-2015-0378\&format $=X M L \& l a n g u a g e=E N$.

48 Op 30 maart 2015 heeft de staatssecretaris voor Veiligheid en Justitie de ACVZ verzocht hem te adviseren hoe in de EU de verantwoordelijkheden ten aanzien van asielzoekers en statushouders over de lidstaten van de EU kunnen worden verdeeld.

49 Bundesamt für Migration und Flüchtlinge, april 2015, zie www.bamf.de/DE/Migration/ AsylFluechtlinge/Asylverfahren/Verteilung/verteilung-node.html.

50 Raad van de Europese Unie, 26 september 2014, 13287/14, bezocht via www.statewatch. org/news/2014/sep/eu-council-save-lives-au-13287-14.pdf, april 2015. 
moeten opvangen. Wij merken op dat elke verdeelsleutel arbitraire elementen bevat. Zo houden de door Oostenrijk gepresenteerde modellen alleen rekening met de kosten van asielprocedures en asielopvang, maar niet met die van grensbewaking en met de aanwezigheid van ongedocumenteerden die geen asiel aanvragen. Het is echter goed dat er naar alternatieven voor het toedelingsysteem van Dublin wordt gezocht. Problematisch aan dit systeem is dat het duur is ${ }^{51}$ en staten aan de buitengrenzen niet beloont voor inspanningen om asielprocedures, opvang en integratie te verbeteren. UNHCR heeft in een voorstel aan de Europese Commissie gepleit voor meer ondersteuning van de lidstaten die te maken hebben met grote aantallen binnenkomers (Griekenland, Italië) en staten die onder druk kunnen komen, zoals Bulgarije, Cyprus, Hongarije en Malta. Ook pleit UNHCR voor een daadwerkelijke toepassing van artikel 16 en 17 lid 2 van Dublin III om ervoor te zorgen dat familieverbanden zo veel mogelijk worden gerespecteerd (UNHCR 2015c).

Het voorstel van UNHCR gaat uit van de veronderstelling dat lidstaten (nog) niet bereid zijn te komen tot een geheel ander toedelingsmechanisme. De door verschillende EU-lidstaten genomen initiatieven laten mogelijk zien dat het draagvlak groeit om binnen afzienbare tijd te komen tot een werkelijke verdeelsleutel. De aantallen asielzoekers die via de zuidelijke buitengrenzen Europa ${ }^{52}$ binnenkomen en de ramingen van het aantal asielzoekers dat een verzoek in Duitsland ${ }^{53} \mathrm{zal}$ indienen, nopen tot een voortvarende besluitvorming.

De Europese Commissie presenteerde op 13 mei 2015 een plan. ${ }^{54}$ Europese landen moeten worden verplicht om asielzoekers uit andere lidstaten op te nemen, als de instroom daar te groot wordt. Elk land zou een asielzoekersquotum moeten krijgen, waarbij onder meer wordt gekeken naar de welvaart, bevolkingsomvang en het aantal werklozen. De Europese Commissie kan voortvarendheid niet worden ontzegd. Nu kijken wat de lidstaten doen.

51 ECRE wijst erop dat de kosten niet inzichtelijk zijn (ECRE 2013, p. 23, 24).

52 In de eerste vier maanden van 2015 zijn zo'n 61.000 personen de Middellandse Zee overgestoken. Circa 1.800 personen vonden de dood. Bron: UNHCR.

53 Duitsland kwam met de schatting dat in 2015 een instroom van 400.000 asielzoekers wordt verwacht. Bron: Deutsche Welle 5 mei 2015.

54 NOS 9 mei 2015, http://nos.nl/artikel/2034763-brussel-wil-asielzoekers-in-geval-van-noodspreiden-over-eu.html en de Volkskrant 9 mei 2015, www.volkskrant.nl/dossiervluchtelingendrama-middellandse-zee/brussel-wil-asielzoekers-spreiden-overlidstaten a4010111/. 


\section{Literatuur}

\section{Boeles e.a. 2014}

P. Boeles, M. den Heijer, G. Lodder \& C. Wouters, European

migration law, Antwerpen: Intersentia 2014.

\section{Brouwer 2013}

E. Brouwer, 'Mutual trust and the Dublin Regulation: Protection of fundamental rights in the EU and the burden of proof', Utrecht Law Review (9) 2013, afl. 1, p. 135-147. Te raadplegen op: www. utrechtlawreview.org/index.php/ ulr/article/viewFile/218/215.

\section{Costello 2012}

C. Costello, 'Dublin-case NS/ME: Finally, an end to blind trust across the EU?', Asiel \& Migrantenrecht 2012, afl. 2, p. 83-92.

\section{EASO 2013}

European Asylum Support Office (EASO), Annual report on the situation of asylum in the European Union 2012, Valetta 2013.

\section{EASO 2014}

European Asylum Support Office (EASO), Annual report on the situation of asylum in the European Union, juli 2014. Te raadplegen op: http://reliefweb.int/ sites/reliefweb.int/files/ resources/EASO-AR-final.pdf.

\section{ECRE 2008}

European Council on Refugees and Exiles (ECRE), Sharing responsibility for refugee protection in Europe: Dublin reconsidered, maart 2008.

\section{ECRE 2013}

European Council on Refugees and Exiles (ECRE), Dublin II regulation: Lives on hold, 2013. Te raadplegen op: www.ecre.org/ component/downloads/ downloads/701.html.

\section{Moreno-Lax 2012}

V. Moreno-Lax, 'Dismantling the Dublin system: M.S.S. v. Belgium and Greece', European Journal of Migration and Law (14) 2012, p. 1-31.

\section{Mouzourakis 2014}

M. Mouzourakis, 'Wrong number?' The use and misuse of asylum data in the European Union, CEPS paper No. 69, december 2014.

\section{UNHCR 2015a}

UN High Commissioner for Refugees (UNHCR), Asylum trends 2014, 2015.

\section{UNHCR 2015b}

UN High Commissioner for Refugees (UNHCR), Central Mediterranean Sea Initiative (CMSI): Action plan, maart 2015. Te raadplegen op: www.refworld.org/ docid/5506a6ae4.html. 


\section{UNHCR 2015c}

UN High Commissioner for Refugees (UNHCR), UNHCR proposals to address current and future arrivals of asylum-seekers, refugees and migrants by sea to Europe, maart 2015. Te raadplegen op: www.refworld.org/docid/ 55016ba14.html. 